\title{
Letter to Editor: Carpal tunnel syndrome due to an atypical deep soft tissue leiomyoma: The risk of misdiagnosis and mismanagement
}

\author{
Giuseppe Granata*1,2, Carlo Martinoli³ , Costanza Pazzaglia1,2, \\ Pietro Caliandro ${ }^{1,2}$, Luca Padua ${ }^{1,2}$ and Diana Ferraro ${ }^{1}$
}

\begin{abstract}
Address: ${ }^{1}$ Institute of Neurology, Università Cattolica del Sacro Cuore, Largo F. Vito 1, 00168 Rome, Italy, ${ }^{2}$ Fondazione Don Carlo Gnocchi, Rome Italy and ${ }^{3}$ Cattedra di Radiologia "R", DICMI, Università di Genova, Italy

Email: Giuseppe Granata* - granata.gius@ hotmail.it; Carlo Martinoli - carlo.martinoli@libero.it;

Costanza Pazzaglia - costanza.pazzaglia@rm.unicatt.it; Pietro Caliandro - p.calandro@rm.unicatt.it; Luca Padua - lpadua@rm.unicatt.it; Diana Ferraro - perdiana@tin.it

* Corresponding author
\end{abstract}

World Journal of Surgical Oncology 2008, 6:22 doi:10.1186/1477-78|19-6-22

Accepted: 20 February 2008

This article is available from: http://www.wjso.com/content/6/1/22

(c) 2008 Granata et al; licensee BioMed Central Ltd.

This is an Open Access article distributed under the terms of the Creative Commons Attribution License (http://creativecommons.org/licenses/by/2.0), which permits unrestricted use, distribution, and reproduction in any medium, provided the original work is properly cited.

\begin{abstract}
A response to Chalidis et al: Carpal tunnel syndrome due to an atypical deep soft tissue leiomyoma: The risk of misdiagnosis and mismanagement. World J Surg Oncol 2007, 5:92.
\end{abstract}

We read with great interest the article by Chalidis et al. [1], on the risk of misdiagnosis and mismanagement of carpal tunnel syndrome due to an atypical deep soft-tissue leiomioma. The authors report a case of a 32 year-old man with symptoms that were attributed to carpal tunnel syndrome (CTS), confirmed by a nerve conduction study, which did not improve after surgery. Magnetic resonance imaging (MRI) was performed and it showed a deep softtissue mass located on the palm of the hand, compatible with leiomyoma. In the discussion, the authors underline the importance, especially in young people, to hypothesize the presence of an underlying tumour when residual symptoms persist after initial surgical treatment.

MRI is known to be a good technique to diagnose nerve or deep soft tissue tumors. Nevertheless, with the introduction of broadband high-frequency transducers, nerve ultrasound (US) is a rapidly expanding technique because it is able to directly visualize nerve abnormalities, provide precise information on surrounding tissues and, in case of
CTS, show whether median nerve compression is due to a tumour or whether it is idiopathic [2].

Usually we diagnose CTS on the basis of the clinical picture and of a neurophysiological evaluation. We use neuroimaging exams in case of atypical neurophysiological findings, atypical clinical symptoms, dissociation between neurophysiological and clinical findings or, as in the case reported by Chalidis [1], when there is not benefit after surgical treatment. In a previous paper [3] we reported five cases of median nerve schwannoma, which clinically simulated a carpal tunnel syndrome and we demonstrated that it is important to examine the median nerve, not only at the wrist, but also out of the wrist.

Both MRI and US allow us to visualize nerve or soft-tissue tumors and they allow us to distinguish between tumors originating from the nerve or from soft tissues. Although it is often impossible to surely differentiate between schwannoma (figure 1) and neurofibroma, which are the most frequent nerve tumors, some US features may distin- 


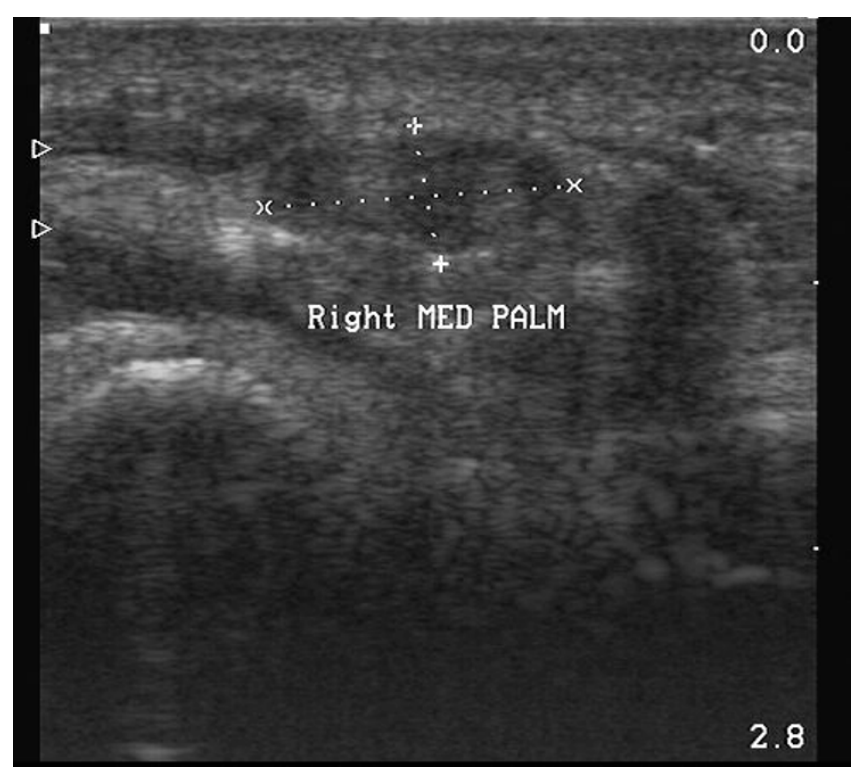

Figure I

Schwannoma of median nerve at palm: A case of Schwannoma: the picture shows an increased cross sectional area of median nerve at palm.

guish between the two [4]. In our experience, MRI always confirmed ultrasonography findings and did not provide any further useful information for the surgeons.

In conclusion, we agree with Chalidis [1] that it is important to add neuroimaging examinations to clinical and neurophysiological assessments in atypical CTS. However, we think that, being US an inexpensive and easily available method which also provides a dynamic examination, it may be the first-line approach to the nerve. The cost-benefit ratio is in favour of using US rather than MRI for a number of reasons: 1) US is less time consuming; it only takes around 5 minutes [5] to carry out an US evaluation of a wrist, while a wrist MRI examination takes around 25 minutes; the MRI may last up to 35 minutes if it is carried out with contrast medium (CM); 2) US is less expansive; in our hospital, the price of a musculoskeletal US is 63 euros (about 92 U.S. dollars), while the price of a MRI of the same district is 344 euros (about 504 U.S. dollars) without CM and 527 euros (about 772 U.S. dollars) with CM (data supplied by the national sanitary system). We think that MRI may be useful in cases in which US gives negative results, but a clinical suspect of tumour persists, or when the tumour is localized in a deep portion of the nerve, which is not easily visualized with US, especially in obese people.

Finally, we want to highlight that US and MRI can also be very useful to visualize nerve or soft-tissue tumors in districts other from the hand [6].

\section{Abbreviations}

Carpal Tunnel Syndrome (CTS); Magnetic Resonance Imaging (MRI); Nerve Ultrasound (US); Contrast Medium (CM).

\section{Competing interests}

The author(s) declare that they have no competing interests.

\section{Authors' contributions}

GGliterature review and preparation of draft manuscript. $\mathrm{MC}, \mathrm{PC}$, and CPhelped in preparation of manuscript. LPhelped in preparing the draft manuscript and edited the final version.

\section{References}

I. Chalidis BE, Dimitriou CG: Carpal tunnel syndrome due to an atypical deep soft tissue leiomyoma: The risk of misdiagnosis and mismanagement. World J Surg Oncol 2007, 5:92.

2. Martinoli C, Bianchi S, Derchi LE: Tendon and nerve sonography. Radiol Clin North Am 1999, 37:69I-7II.

3. Padua L, Pazzaglia C, Insola A, Aprile I, Caliandro P, Rampoldi M, Bertolini $C$, Tonali P: Schwannoma of the median nerve may mimic carpal tunnel syndrome. Neurol Sci 2006, 26:430-234.

4. Beggs I: Sonographic appearances of nerve tumors. J Clin Ultrasound 1999, 27:363-368.

5. Duncan I, Sullivan P, Lomas F: Sonography in the diagnosis of carpal tunnel syndrome. AJR Am J Roentgenol 1999, I73:68I-684.

6. Padua L, Aprile I, Pazzaglia C, Frasca G, Caliandro P, Tonali P, Martinoli $C$ : Contribution of ultrasound in a neurophysiological lab in diagnosing nerve impairment: A one-year systematic assessment. Clin Neurophysiol 2007, I I 8: I I77-I 178.

Publish with Bio Med Central and every scientist can read your work free of charge

"BioMed Central will be the most significant development for disseminating the results of biomedical research in our lifetime. "

Sir Paul Nurse, Cancer Research UK

Your research papers will be:

- available free of charge to the entire biomedical community

- peer reviewed and published immediately upon acceptance

- cited in PubMed and archived on PubMed Central

- yours - you keep the copyright 